\title{
ABO histo-blood group and risk of respiratory atopy in children: a review of published evidence
}

This article was published in the following Dove Press journal:

Pediatric Health, Medicine and Therapeutics

\section{Samuel N Uwaezuoke' \\ Joy $N$ Eze' \\ Adaeze C Ayuk' \\ Ikenna $\mathrm{K} \mathrm{Ndu}{ }^{2}$}

'Department of Paediatrics, University of Nigeria Teaching Hospital

(UNTH), Ituku-Ozalla Enugu, Nigeria;

${ }^{2}$ Department of Paediatrics, Enugu

State University Teaching Hospital,

Enugu, Nigeria
Correspondence: Samuel N Uwaezuoke Department of Paediatrics, University of Nigeria Teaching Hospital (UNTH) Ituku-Ozalla Enugu, PMB 01 I 29 Enugu, 40000 I Nigeria

Tel +2348033248108

Email snuwaezuoke@yahoo.com

\begin{abstract}
Besides their fundamental role in transfusion medicine, $\mathrm{ABO}$ and other histo-blood group antigens are associated with the pathogenesis of some human diseases such as malignancy and thrombosis. Reports also show a possible relationship with the risk of asthma and other forms of respiratory atopy. This paper aims to critically review the current evidence linking ABO histo-blood group with the risk of respiratory atopy in children and adults. A literature search was conducted with PubMed to gather baseline data about this relationship. The search extended to studies published within the past 45 years. First, the molecular mechanism underpinning the role of $\mathrm{ABO}$ antigenic system in human diseases comprises a fascinating relationship with von Willebrand factor and several pro-inflammatory and adhesion molecules. Second, specific blood group types vary with asthma phenotypes; severe asthma is associated with B phenotype, while mild and moderate asthma is associated with $\mathrm{O}$ and $\mathrm{A}$ phenotypes. Third, $\mathrm{O}$ phenotype has been linked to allergic rhinitis but only in males. Furthermore, asthma risk is related to $\mathrm{O} /$ Lewis negative/secretor phenotypes, while a significant relationship has also been established with B phenotype but not with A and O phenotypes. However, one study failed to establish a significant relationship with any of the ABO blood group antigens. In conclusion, there is no unanimity on the specific histo-blood groups linked to respiratory atopy risk, although asthma phenotypes are associated with specific blood groups. Despite the prospect that this relationship holds for the use of blood-group typing in evaluating respiratory atopy risk in children, more evidence-based studies are still required for its validation.
\end{abstract}

Keywords: blood-group phenotypes, asthma phenotypes, B phenotype, von Willebrand factor, asthma risk, blood-group typing

\section{Introduction}

The antigens of the $\mathrm{ABO}$ histo-blood group consist of complex carbohydrate molecules expressed on the surface of erythrocytes, platelets, epithelium, sensory neurons and vascular endothelium. ${ }^{1}$ Apart from their fundamental role in transfusion medicine, there is increasing evidence linking these antigens with the pathogenesis of several morbid states such as infectious, cardiovascular and neoplastic diseases..$^{2-5}$ For instance, some authors have reported a significant relationship between ABO blood group and neoplasms such as gastric, pancreatic and renal cell cancers. ${ }^{5-7}$ Other reports also show a similar relationship between the blood group system and cardiovascular diseases, especially venous and arterial thrombosis. ${ }^{8-10}$

Furthermore, blood group $\mathrm{O}$ has been noted to confer some protection against infections like severe Plasmodium falciparum malaria through a well-defined 
mechanism. ${ }^{11-14}$ Specifically, blood group B is associated with increased risk of severe falciparum malaria infection, ${ }^{14}$ although findings from another study indicate that blood groups A, B and AB generally confer more susceptibility to Plasmodium falciparum infection when compared to blood group O. ${ }^{15}$ Other authors have also documented a possible relationship between ABO blood group antigens and susceptibility to Helicobacter pylori infection. ${ }^{16}$ Research on ABO histo-blood group and other morbidity risks has also focused on its relationship with respiratory atopy in children and adults. ${ }^{17-23}$ However, there is no unanimity in the findings of these studies. Whereas one study suggests that there is no significant relationship between $\mathrm{ABO}$ histo-blood group and bronchial asthma, ${ }^{23}$ other studies report that the histo-blood group is significantly associated with the disease and other forms of respiratory atopy as well. ${ }^{17-22}$

Within the past decades, bronchial asthma has emerged as the most common non-communicable respiratory disease affecting children worldwide. ${ }^{24}$ It is a chronic inflammatory disorder due to abnormal stimulation of the immune system, for instance, by air-borne allergens, and is characterized by bronchial hyper-reactivity, reversible airway obstruction and mucus overproduction. ${ }^{25}$ Defective responses of pulmonary resident cells, particularly those associated with mucosal epithelium, represent important factors in the pathogenesis of the disorder. ${ }^{26}$ Since the ABO histo-blood group antigens are also expressed on mucosal epithelial cells, their association with asthma risk is thus a plausible hypothesis. In addition, if this relationship is subsequently established to be evidence based, ABO blood typing can potentially form part of the strategy for assessing asthma risk.

This paper aims to critically review the current evidence linking the $\mathrm{ABO}$ histo-blood group antigens with the risk of respiratory atopy in children and adults.

\section{Literature search: strategy and outcome}

In line with the review objective, a combination of search terms were used to gather articles from the PubMed database between June and September 2017. Articles published within the past 45 years were included. Search terms like "histo-blood group antigen and disease" were entered, and 137 publications were retrieved; "histo-blood group antigen and cancer" yielded 95 publications; "histo-blood group antigen and allergy" yielded 7; "histo-blood group antigen and asthma" gave 4; "histo-blood group antigen and infestation" gave 4, while "ABO blood group system and asthma" yielded 27 publications. A total of 274 publications were screened to remove duplicate studies and to exclude those that failed to meet the review objective and criteria. After exclusion of 170 publications, the remaining 104 publications formed the list from which 8 original articles were selected for review. A few web links, textbooks and published review articles were also cited.

\section{Histo-blood group systems and risk of respiratory atopy: the published evidence}

The antigens of the $\mathrm{ABO}$ blood group system are conventionally designated as $\mathrm{A}, \mathrm{B}$ and $\mathrm{H}$. The nomenclature is based on the outcome of the following molecular events. The $\mathrm{A}$ and $\mathrm{B}$ alleles encode marginally distinct glycosyltransferases that join $\mathrm{N}$-acetylgalactosamine and D-galactose to a shared precursor side chain (called the $\mathrm{H}$ determinant), which is then transformed into $\mathrm{A}$ or $\mathrm{B}$ antigens, respectively. ${ }^{27} \mathrm{By}$ contrast, the $\mathrm{O}$ alleles do not encode for a functional enzyme, so that $\mathrm{OO}$ carriers lack glycosyltransferases and thus express the unchanged $\mathrm{H}$ antigenic structure, which represents the phenotypic marker of the O blood group. ${ }^{27}$ The molecular mechanism for the role of $\mathrm{ABO}$ antigenic system in human diseases consists of a fascinating relationship with von Willebrand factor and several pro-inflammatory and adhesion molecules. ${ }^{28}$ The molecular basis for the link between this antigenic system and the risk of non-respiratory diseases has been well established, especially in certain cardiovascular disease ${ }^{29-31}$ and specific malignancies. ${ }^{32-35}$

The relationship between histo-blood group systems and the risk of respiratory atopy in both children and adults has also become a subject of research over the years. The secretor gene (FUT2), which encodes for 2-alpha-fucosyltransferase, and the ABO blood group system, which encodes for glycosyltransferases, act in synergy to build up oligosaccharide moieties in exocrine secretion systems, including the respiratory tract. ${ }^{36}$ The composition of the glycoconjugate profile of the respiratory epithelium and of the exocrine secretions is partly controlled by mutual interactions between the ABO $(A B O ; 9 \mathrm{q} 34.1)$ and secretor (FUT2; 19q13.3) genes and is affected by their ability to assume different forms. ${ }^{36,37}$ Given that these profiles represent important risk factors for adherence of microorganisms and allergens, ${ }^{38}$ it is possible that the action of these different forms of $A B O$ and FUT2 genes influences the risk for other forms of respiratory atopy apart from asthma. Thus, the relationship between histo-blood group systems and respiratory atopy obviously has a pathophysiologic basis. Eight studies were reviewed; four of them were conducted among adult subjects, ${ }^{18,20,22,39}$ three among children, ${ }^{17,19,21}$ while one study was conducted 
among both pediatric and adult subjects. ${ }^{23}$ Although these published reports are few in number, there is no unanimity in their findings (Tables 1 and 2).

\section{Studies conducted among adult subjects}

In a cross-sectional study among adult subjects in France, some investigators examined the role of Lewis, salivary $\mathrm{ABH}$ secretor, and red cell blood group $\mathrm{ABO}$ systems on lung function, wheezing and asthma in a cohort of 228 coal miners, taking into consideration the effect of confounders like environmental factors on these associations. ${ }^{18}$ The Lewis antigen system is a histo-blood group system based upon the Lewis gene (FUT3) and the secretor gene (FUT2). Both genes have dominant alleles (Le and Se), which code for enzymes with fucosyltransferase activity, and there exists two main types of Lewis antigens ( $(\mathrm{Le}-\mathrm{a}$ and $\mathrm{Le}-\mathrm{b})$ with three common phenotypes, Le $(\mathrm{a}+\mathrm{b})$, Le $(\mathrm{a}-\mathrm{b}+)$ and Le $\left(\mathrm{a}^{-} \mathrm{b}-\right) \cdot{ }^{40}$ In the study under review, ${ }^{18}$ a significant relationship was noted between asthma risk and non-secretor phenotype. Similarly, there was a significant relationship between lower pulmonary function and higher prevalences of wheezing/asthma, and Lewis-negative or non-secretor subjects of blood group O. The ABO, Lewis and secretor phenotypes did not account for the potential genetic diversity of subjects toward smoking, but alcohol consumption appeared to protect the pulmonary function in Lewis-negative subjects. ${ }^{18}$ In a nutshell, the study findings indicate that asthma risk is significantly associated with blood group $\mathrm{O}$ and Lewis negative phenotypes. Although the authors assessed three histo-blood group systems in their subjects, they did not enroll age- and sex-matched controls. Asthma risk was also not determined by the estimation of odds ratio (Table 1).

In a related Brazilian study conducted among 168 adult subjects older than 18 years, the authors showed that $\mathrm{O}$ phenotype was significantly associated with the risk of allergic rhinitis but only in males $(\mathrm{OR}=2.8, \mathrm{CI}=1.385-5.616) .{ }^{20}$ Despite the small sample size and the assessment of only ABO histo-blood group, 168 controls were matched for age and sex with the subjects (Table 1). The study particularly underscores the possible role of sex in increasing atopy risk. Despite the unclear biologic basis for the relationship between $O$ phenotype and allergic rhinitis in the male sex, the interaction between the $\mathrm{O}$ blood group and inflammatory immune response in the airway mucosa is thought to increase the risk for allergic rhinitis in men. ${ }^{20}$ The $A B O$ gene, which controls the $\mathrm{ABO}$ histo-blood group system, is autosomal in nature. Moreover, there is no evidence that its phenotypic expression and pattern of inheritance are influenced by sex. ${ }^{41}$ However, a report suggests that the expression of inflammatory proteins in nasal secretions appears higher in men with seasonal allergic rhinitis than in their female counterparts. ${ }^{42}$

Table I Histo-blood group systems and risk of respiratory atopy: summary of studies in adults

\begin{tabular}{|c|c|c|c|c|c|}
\hline Study & $\begin{array}{l}\text { Type of study (study } \\
\text { population) }\end{array}$ & $\begin{array}{l}\text { Histo-blood group } \\
\text { systems }\end{array}$ & $\begin{array}{l}\text { Atopy risk (OR, } \\
95 \% \mathrm{Cl})\end{array}$ & $\begin{array}{l}\text { Study } \\
\text { strengths }\end{array}$ & Study limitations \\
\hline Kauffmann et al $^{18}$ & $\begin{array}{l}\text { Cross-sectional study ( } 228 \\
\text { adult coal miners) }\end{array}$ & $\begin{array}{l}\text { Blood group O/Lewis } \\
\text { negative }\end{array}$ & Asthma risk (NA) ${ }^{a}$ & $\begin{array}{l}\text { Assessed the } \\
\text { three histo-blood } \\
\text { groups }\end{array}$ & $\begin{array}{l}\text { No controls used in the } \\
\text { study }\end{array}$ \\
\hline Falsarella et $\mathrm{al}^{20}$ & $\begin{array}{l}\text { Cross-sectional case- } \\
\text { control study (168 adults } \\
>18 \text { years, } 168 \text { matched } \\
\text { controls) }\end{array}$ & Blood group $\bigcirc$ & $\begin{array}{l}\text { Allergic rhinitis risk } \\
(2.8,1.385-5.616)^{b}\end{array}$ & $\begin{array}{l}\text { Controls } \\
\text { matched for age } \\
\text { and sex }\end{array}$ & $\begin{array}{l}\text { Small sample size } \\
\text { Only } A B O \text { histo-blood } \\
\text { group was assessed }\end{array}$ \\
\hline Alo et $\mathrm{al}^{22}$ & $\begin{array}{l}\text { Cross-sectional case- } \\
\text { control study ( } 200 \text { adult } \\
\text { asthmatics, } 100 \text { adult } \\
\text { controls) }\end{array}$ & Blood group $A$ & Asthma risk (NA) ${ }^{a}$ & $\begin{array}{l}\text { Assessed } A B O \\
\text { and Rhesus } \\
\text { phenotypes }\end{array}$ & $\begin{array}{l}\text { Age range of subjects not } \\
\text { stated } \\
\text { Controls not age or sex } \\
\text { matched } \\
\text { Small sample size } \\
\text { Odds ratio not estimated }\end{array}$ \\
\hline $\begin{array}{l}\text { Khetsuriani and } \\
\text { Gamkrelidze }{ }^{39}\end{array}$ & $\begin{array}{l}\text { Cross-sectional case- } \\
\text { control study ( } 293 \text { subjects } \\
\text { with respiratory atopy, } 83 \\
\text { with intrinsic asthma and } \\
215 \text { controls) }\end{array}$ & $\begin{array}{l}\mathrm{O}(\mathrm{I}), \mathrm{MN}, \mathrm{O}(\mathrm{I}) \mathrm{MN}, \\
\text { MNFya(-), O(I)Fya(-) } \\
\text { and } \mathrm{O}(\mathrm{I}) \mathrm{MNFya}(-) \\
\text { phenotypes } \\
\mathrm{B}(\mathrm{III}), \mathrm{M} \text { and } \mathrm{B}(\mathrm{III}) \mathrm{M} \\
\text { phenotypes } \\
\text { O(I) and MN } \\
\text { phenotypes }\end{array}$ & $\begin{array}{l}\text { Respiratory atopic } \\
\text { disease risk } \\
\text { Severe atopic } \\
\text { bronchial asthma risk } \\
\text { Mild-to-moderate } \\
\text { atopic bronchial } \\
\text { asthma risk }\end{array}$ & $\begin{array}{l}\text { Assessed ABO, } \\
\text { Rh, MNSs, P, } \\
\text { Duffy, and Kell } \\
\text { histo-blood } \\
\text { systems }\end{array}$ & Controls not matched \\
\hline
\end{tabular}

Note: ${ }^{a}$ Significant association; ${ }^{\mathrm{b}}$ significant association in males only.

Abbreviations: OR, odds ratio; NA, not available. 
Table 2 Histo-blood group systems and risk of respiratory atopy: summary of studies in children

\begin{tabular}{|c|c|c|c|c|c|}
\hline Study & $\begin{array}{l}\text { Type of study (study } \\
\text { population) }\end{array}$ & $\begin{array}{l}\text { Histo-blood group } \\
\text { systems }\end{array}$ & $\begin{array}{l}\text { Atopy risk (OR, } \\
95 \% \mathrm{Cl} \text { ) }\end{array}$ & Study strengths & Study limitations \\
\hline Chen et $\mathrm{al}^{17}$ & $\begin{array}{l}\text { Cross-sectional case- } \\
\text { control study (I35 } \\
\text { asthmatic children, } 161 \\
\text { age-matched controls) }\end{array}$ & $\begin{array}{l}\text { Blood group O/ } \\
\text { secretor phenotypes } \\
\text { Blood group O/Lewis } \\
(a-b-)\end{array}$ & $\begin{array}{l}\text { Asthma risk }(2.7, \\
1.126-6.033)^{\mathrm{a}} \\
\text { Asthma risk (3.6, } \\
1.080-11.963)^{\mathrm{a}}\end{array}$ & $\begin{array}{l}\text { Studied combined effect } \\
\text { of three histo-blood } \\
\text { groups } \\
\text { Study population } \\
\text { randomly selected }\end{array}$ & $\begin{array}{l}\text { Small sample size } \\
\text { Controls matched for } \\
\text { age but not sex }\end{array}$ \\
\hline Ronchetti et $\mathrm{al}^{21}$ & $\begin{array}{l}\text { Cross-sectional case- } \\
\text { control study ( } 165 \\
\text { asthmatic children, } 362 \\
\text { infants) }\end{array}$ & $\begin{array}{l}A, B \text { or } A B / \text { non- } \\
\text { secretor }\end{array}$ & $\begin{array}{l}\text { Asthma risk for } \\
<1 \text { year olds }(2.6 \text {, } \\
0.88-7.30), 1-5 \text { years } \\
(2.1,0.86-4.91)^{\mathrm{a}, \mathrm{b}}\end{array}$ & $\begin{array}{l}\text { Assessed both } A B O / \\
\text { secretor phenotypes }\end{array}$ & $\begin{array}{l}\text { Controls not matched } \\
\text { for age or sex }\end{array}$ \\
\hline Bijanzadeh et $\mathrm{a}^{23}$ & $\begin{array}{l}\text { Cross-sectional case- } \\
\text { control study ( } 200 \\
\text { asthmatic children and } \\
\text { adults, } 2000 \text { controls) }\end{array}$ & $\begin{array}{l}\text { Blood groups } O, B \text {, } \\
A \text { and } A B \text { (in that } \\
\text { order) }\end{array}$ & Asthma risk (NA) & Controls were used & $\begin{array}{l}\text { Controls not matched } \\
\text { Odds ratio not } \\
\text { estimated }\end{array}$ \\
\hline $\begin{array}{l}\text { De la Vega AR } \\
\text { et al }{ }^{19}\end{array}$ & $\begin{array}{l}\text { Cross-sectional } \\
\text { case-control study } \\
\text { (II5 children, I00I } \\
\text { controls) }\end{array}$ & $\begin{array}{l}\text { Blood groups } A \\
\text { and } O \\
\text { Gene frequencies } \\
\text { for } A(p) \text { and } O(r) \\
\text { different for subjects } \\
\text { and controls }\end{array}$ & Asthma risk (NA) & $\begin{array}{l}\text { Assessed } A B O \text { and } \\
\text { Rhesus phenotypes } \\
A B O \text { gene frequencies } \\
\text { were calculated }\end{array}$ & Controls not matched \\
\hline
\end{tabular}

Note: ${ }^{a}$ Significant association; bsignificant association in males only; ${ }^{c}$ no significant association. Abbreviations: OR, odds ratio; NA, not available.

A recent related study was conducted in Nigeria among 200 adult asthmatics and 100 adult controls. ${ }^{22}$ The major finding of this study was the significant relationship between asthma risk and blood group A. Despite the authors' evaluation of both $\mathrm{ABO}$ and Rhesus histo-blood group systems, they failed to indicate the age range of their study subjects and controls. As shown in Table 1, other study limitations include the relatively small sample size and the fact that the controls were not matched for age or sex with the subjects. Worse still, the odds ratio was apparently not estimated in evaluating asthma risk.

Finally, a cross-sectional case-control study in Georgia investigated the role of several histo-blood group systems (such as ABO, Rh, MNSs, P, Duffy, Kell) in the predisposition to and development of respiratory atopic disease..$^{39}$ The authors enrolled 293 subjects with respiratory atopic disease and 83 subjects with intrinsic bronchial asthma with 215 healthy controls. Associations between the histo-blood groups and respiratory atopic disease (atopic bronchial asthma and pollinosis), the severity of the disease and the type of sensitization were established, involving the ABO, MNSs and Duffy systems. Carriers of phenotypes O(I), MN, O(I) MN, MNFya(-), O(I)Fya(-) and O(I)MNFya(-) were noted to have a significantly higher risk for respiratory atopic disease. ${ }^{39}$ While the risk for severe atopic bronchial asthma was higher in patients with $\mathrm{B}(\mathrm{III}), \mathrm{M}$ and $\mathrm{B}(\mathrm{III}) \mathrm{M}$ phenotypes, the patients with groups $\mathrm{O}(\mathrm{I})$ and $\mathrm{MN}$ had a mild-to-moderate degree of asthma severity. These findings suggest that asthma phenotypes are probably the determinants of the predominant histo-blood groups. In other words, since it is now known that different asthma phenotypes exist, perhaps only a specific asthma phenotype will show associations with the histo-blood groups. Given the established influence of male sex on atopy risk, ${ }^{20,42}$ the authors' assessment of several histo-blood group systems remains one of the advantages of the study as it has highlighted the associations of different blood group phenotypes with different degrees of asthma severity (Table 1).

\section{Studies conducted among pediatric subjects}

In a cross-sectional case-control study that evaluated 115 asthmatic children with 1001 healthy voluntary blood donors, the investigators determined the distribution of their $\mathrm{ABO}$ histo-blood groups and also estimated their gene frequencies. ${ }^{19}$ There was no difference between the Rhesus systems in both groups; however, the ABO system showed a predominance of $\mathrm{A}$ and $\mathrm{O}$ phenotypes among the subjects with asthma. In addition, gene frequencies of $\mathrm{A}$ and $\mathrm{O}$ were clearly different for the asthmatic children and the controls. The authors did not observe any difference in blood groups $\mathrm{B}$ and $\mathrm{AB}$, nor in the gene frequency of group $\mathrm{B}$. More importantly, the difference in the distribution of $\mathrm{A}$ and $\mathrm{O}$ phenotypes between the control and asthmatic groups was found to be highly significant. Nevertheless, the sample size 
of this study was relatively small; the relatively large-sized controls were not matched with the subjects and there was no estimated odds ratio. The strong points of the study include the estimation of $A B O$ gene frequencies and the assessment of $\mathrm{ABO} /$ Rhesus blood groups in the study population (Table 2).

Other researchers in Taiwan examined the relationship between $\mathrm{ABO}$ system, Lewis and secretor genetic complex with risk of asthma. ${ }^{17}$ In their study, 136 children with asthma and 161 age-matched controls were randomly selected from a childhood-asthma survey conducted in primary schools. The risk of asthma was noted to be higher in secretor subjects than in the study controls ( $\mathrm{OR}=1.7, \mathrm{CI}=1.022-2.938)$. However, when the combined effect of the three blood antigenic systems was analyzed, asthma risk was observed to be significant in subjects with blood group $\mathrm{O} /$ secretor phenotypes $(\mathrm{OR}=2.7$, $\mathrm{CI}=1.126-6.033)$ and group $\mathrm{O} /$ Lewis recessive genotype (OR=3.6, CI=1.080-11.963). ${ }^{17}$ Obviously, group O/secretor phenotype and $\mathrm{O} /$ Lewis recessive genotype were significantly associated with asthma risk. Despite the small sample size and the fact that the controls were not matched for sex with the subjects, the random selection of the subjects and the evaluation of the combined effect of the three histo-blood groups were some of the merits of this study.

In Italy, a cross-sectional case-control study was conducted among 165 asthmatic children using 362 infants as controls. ${ }^{21}$ Interestingly, A, B or AB/non-secretor phenotypes were significantly associated with asthma risk in subjects aged 1 year or less $(\mathrm{OR}=2.6, \mathrm{CI}=0.88-7.30)$ and in those aged $1-5$ years $(\mathrm{OR}=2.1, \mathrm{CI}=0.86-4.91)$. Although the authors studied the association of both the $\mathrm{ABO}$ and secretor blood group systems with asthma risk, the controls were, however, not matched for age or sex.

\section{The study conducted among both pediatric and adult subjects}

In one study conducted in India, the ABO blood group of 200 children and adults with bronchial asthma and that of 2000 healthy subjects taken as controls were investigated. ${ }^{23}$ The authors reported group $\mathrm{O}$ as the most prevalent histo-blood group with rates of $43.5 \%$ and $43.6 \%$ among the patients and the controls, respectively; it was followed by blood groups $\mathrm{B}, \mathrm{A}$ and $\mathrm{AB}$ in that order. However, in the distribution of different histo-blood groups, the difference between these patients and the controls was observed to be statistically nonsignificant, making the authors to conclude that ABO blood group status was not significantly associated with asthma risk among the studied population. ${ }^{23}$ Again, as part of the limitations of the study, the controls were also not matched for age and sex with the subjects, and the odds ratio was not calculated as the means of assessing asthma risk in the study population.

\section{$A B O$ blood group link with other atopies and the effect of asthma comorbidities}

Generally, obvious disparities exist between the histo-blood group antigenic types in their responses to atopy. For instance, in a study of 241 patients with grass-pollen hay fever, blood group B subjects showed a higher tendency for pollen allergies when compared to other blood groups, followed by blood group $\mathrm{O} .{ }^{43}$ However, the limitation of this study is that it was essentially retrospective in nature. Thus, a valid conclusion cannot be safely made on this relationship based on this study methodology. On the other hand, a cross-sectional casecontrol study of 239 patients in Germany who had atopic conditions (atopic dermatitis, hay fever, allergic rhinitis, asthma and acute urticaria), showed that the incidence of blood group antigens A and B was higher in these patients than in the 151 selected controls. ${ }^{44}$ Although the sample size was small, being a case-control study, however, strengthens the evidence. In addition, the pros of the study consist of the inclusion of data on the phenotype and gene distribution of 15 genetic blood polymorphisms such as $\mathrm{ABO}, \mathrm{MNSs}$, rhesus, P, Kell, Duffy, Kidd and 6-PGD. ${ }^{44}$ Their findings further support the hypothesis that there may be a relationship between specific phenotypes and atopic predisposition.

Finally, the co-existence of asthma with other morbidities appears to alter the related histo-blood groups in patients. ${ }^{45-48}$ According to one study, a relationship with blood group $\mathrm{O}$ could be demonstrated in patients who had both arthritis and asthma, ${ }^{45}$ whereas patients with both diabetes and asthma presented more with group A phenotype. ${ }^{46}$ Moreover, blood group B was associated with greater severity of chronic inflammatory pulmonary diseases, ${ }^{47}$ as well as with asthma from chronic lung inflammation. ${ }^{48}$ In spite of these observations, no reasons have yet been advanced to explain the effects of these asthma comorbidities on the associated histo-blood groups.

\section{Conclusion}

Although reports consistently show a relationship between $\mathrm{ABO}$ histo-blood group and the risk of venous/arterial thrombosis and gastric/pancreatic malignancies, there is no unanimity in the findings regarding the association of $\mathrm{ABO}$ and other histo-blood groups with the risk of respiratory atopy. Nonetheless, much of the evidence from various studies indicates that the association with respiratory atopy 
risk remains significant. Further research using systematic reviews with meta-analyses and case-control studies with large sample sizes are recommended to validate the emerging evidence on this relationship, which may in future support the use of blood-group typing in evaluating respiratory atopy risk in children.

\section{Acknowledgment}

The authors acknowledge the invaluable information obtained from the article by Franchini and Lippi. ${ }^{28}$

\section{Disclosure}

The authors report no conflicts of interest in this work.

\section{References}

1. Franchini M, Liumbruno GM. ABO blood group: old dogma, new perspectives. Clin Chem Lab Med. 2013;51:1545-1553.

2. Franchini M, Bonfanti C. Evolutionary aspects of ABO blood group in humans. Clin Chim Acta. 2015;444:66-71.

3. Liumbruno GM, Franchini M. Beyond immunohaematology: the role of the ABO blood group in human diseases. Blood Transfus. 2013;11(4):491-499.

4. Liumbruno GM, Franchini M. Hemostasis, cancer, and ABO blood group: the most recent evidence of association. JThromb Thrombolysis. 2014;38(2):160-166.

5. Franchini M, Favaloro EJ, Targher G, Lippi G. ABO blood group, hypercoagulability, and cardiovascular and cancer risk. Crit Rev Clin Lab Sci. 2012;49(4):137-149.

6. Greer JB, Yazer MH, Raval JS, Barmada MM, Brand RE, Whitcomb DC. Significant association between ABO blood group and pancreatic cancer. World J Gastroenterol. 2010;16(44):5588-5591.

7. Joh HK, Cho E, Choueiri TK. ABO blood group and risk of renal cell cancer. Cancer Epidemiol. 2012;36(6):528-532.

8. Dentali F, Sironi AP, Ageno W, et al. Non-O blood type is the commonest genetic risk factor for VTE: results from a meta-analysis of the literature. Semin Thromb Hemost. 2012;38(5):535-548.

9. Dentali F, Sironi AP, Ageno W, Crestani S, Franchini M. ABO blood group and vascular disease: an update. Semin Thromb Hemost. 2014;40(1):49-59.

10. Franchini M, Mannucci PM. ABO blood group and thrombotic vascular disease. Thromb Haemost. 2014;112(6):1103-1109.

11. Rowe JA, Handel IG, Thera MA, et al. Blood group O protects against severe Plasmodium falciparum malaria through the mechanism of reduced rosetting. Proc Natl Acad Sci U S A. 2007;104(44): 17471-17476.

12. Pathirana SL, Alles HK, Bandara S, et al. ABO-blood-group types and protection against severe, Plasmodium falciparum malaria. Ann Trop Med Parasitol. 2005;99(2):119-124.

13. Tadesse H, Tadesse K. Assessing the association of severe malaria infection and $\mathrm{ABO}$ blood groups in northwestern Ethiopia. $J$ Vector Borne Dis. 2013;50(4):292-296.

14. Panda AK, Panda SK, Sahu AN, Tripathy R, Ravindran B, Das BK. Association of $\mathrm{ABO}$ blood group with severe falciparum malaria in adults: case control study and meta-analysis. Malar J. 2011;10:309.

15. Zerihun T, Degarege A, Erko B. Association of ABO blood group and Plasmodium falciparum malaria in Dore Bafeno Area, Southern Ethiopia. Asian Pac J Trop Biomed. 2011;1(4):289-294

16. Sharara AI, Abdul-Baki H, ElHajj I, Kreidieh N, Kfoury Baz EM. Association of gastroduodenal disease phenotype with ABO blood group and Helicobacter pylori-specific serotypes. Dig Liver Dis. 2006;38(11):829-833.
17. Chen YL, Chen JC, Lin TM, et al. ABO/secretor genetic complex is associated with the susceptibility of childhood asthma in Taiwan. Clin Exp Allergy. 2005;35(7):926-932.

18. Kauffmann F, Frette C, Pham QT, Nafissi S, Bertrand JP, Oriol R. Associations of blood group-related antigens to FEV1, wheezing, and asthma. Am J Respir Crit Care Med. 1996;153(1):76-82.

19. De la Vega AR, Gómez Cortés J, Bacallao Gallestey J. Genetic polymorphism of $\mathrm{ABO}$ and $\mathrm{Rh}$ system in relation to bronchial asthma: preliminary report. Allergol Immunopathol (Madr). 1976;4(5):305-310.

20. Falsarella N, Ferreira A, Nakashima F, de Mattos Cde C, de Mattos LC. Evidence of an association between the $\mathrm{O}$ blood group and allergic rhinitis. Rev Bras Hematol Hemoter. 2011;33(6):444-448.

21. Ronchetti F, Villa MP, Ronchetti R, et al. ABO/Secretor genetic complex and susceptibility to asthma in childhood. Eur Respir J. 2001;17:1236-1238.

22. Alo MN, Eze UA, Yaro SA, Jubril B, Nwanoke NN. Relationship between $\mathrm{ABO}$ and rhesus blood groups and susceptibility to asthma within Sokoto metropolis, Nigeria. Int J Immunol. 2015;3:37-41.

23. Bijanzadeh M, Ramachandra NB, Mahesh PA, Savitha MR, Manjunath BS, Jayaraj BS. Lack of association between asthma and ABO blood group. Lung. 2009;187(6):389-392

24. WHO. Asthma (Fact sheet No. 307). Geneva: World Health Organization; 2006. Available from: http://www.who.int/mediacentre/factsheets/ fs307/en/index.html. Accessed September 7, 2017.

25. Bierbaum S, Heinzmann A. The genetics of bronchial asthma in children. Respir Med. 2007;101(7):1369-1375.

26. Martinez FD, Vercelli D. Asthma. Lancet. 2013;382(9901):1360-1372.

27. Lowe JB. The blood group-specific human glycosyltransferases. Baillieres Clin Haematol. 1993;6(2):465-490.

28. Franchini M, Lippi G. The intriguing relationship between the ABO blood group, cardiovascular disease and cancer. BMC Med. 2015;13:7.

29. Chen $Y$, Chen C, Ke X, et al. Analysis of circulating cholesterol levels as a mediator of an association between $\mathrm{ABO}$ blood group and coronary heart disease. Circ Cardiovasc Genet. 2014;7(1):43-48.

30. Franchini M, Capra F, Targher G, Montagnana M, Lippi G. Relationship between $\mathrm{ABO}$ blood group and von Willebrand factor levels: from biology to clinical implications. Thromb J. 2007;5:14.

31. Jenkins PV, O’Donnell JS. ABO blood group determines plasma von Willebrand factor levels: a biologic function after all? Transfusion. 2006;46(10):1836-1844.

32. Franchini M, Frattini F, Crestani S, Bonfanti C, Lippi G. von Willebrand factor and cancer: a renewed interest. Thromb Res. 2013;131(4):290-292.

33. Wolpin BM, Chan AT, Hartge P, et al. ABO blood group and the risk of pancreatic cancer. J Natl Cancer Inst. 2009;101(6):424-431.

34. Edgren G, Hjalgrim J, Rostgaard K, et al. Risk of gastric cancer and peptic ulcers in relation to ABO blood type: a cohort study. Am J Epidemiol. 2010;172(11):1280-1285.

35. Etemadi A, Kamangar F, Islami F, et al. Mortality and cancer in relation to $\mathrm{ABO}$ blood group phenotypes in the Golestan Cohort study. $B M C$ Med. 2015;13:8

36. Oriol R. Abo Hh, Lewis and secretion: serology, genetics and tissue distribution. In: Cartron JP, Rouger P, editors. Blood Cell Biochemistry: Molecular Basis of Human Blood Group Antigens. New York: Plenum; 1995:37-73.

37. Oriol R, Le Pendu J, Mollicone R. Genetics of ABO, H, X and related antigens. Vox Sang. 1986;51(3):161-162.

38. Henry SM. Molecular diversity in the biosynthesis of GI tract glycoconjugates: a blood-group-related chart of microorganism receptors. Transfus Clin Biol. 2001;8(3):226-230.

39. Khetsuriani NG, Gamkrelidze AG Erythrocyte antigens as immunogenetic markers of respiratory atopic diseases in Georgians. J Investig Allergol Clin Immunol. 1995;5(1):35-39.

40. Mais DD. ASCP Quick Compendium of Clinical Pathology. 2nd ed. Bethesda, MD: ASCP Press; 2008.

41. Schenkel-Brunner H. Human Blood Groups: Chemical and Biochemical Basis of Antigen Specificity. Vien: Springer-Verlag; 2000. 
42. Barrenäs F, Andersson B, Cardell LO, et al. Gender differences in inflammatory proteins and pathways in seasonal allergic rhinitis. Cytokine. 2008;42(3):325-329.

43. Koers WJ, Houben GF, Berrens L. Blood groups ABO and grass-pollen hay fever. Allerg Immunol (Leipz). 1989;35(3):167-172.

44. Brachtel R, Walter H, Beck W, Hilling M. Associations between atopic diseases and the polymorphic systems ABO, Kidd, Inv and red cell acid phosphatase. Hum Genet. 1979;49(3):337-348.

45. Ksenofontov IuP. [Genetic blood markers in arthritic diseases]. Genetika. 1978;14(2):359-364. Russian [with English abstract].
46. Nikitin AV, Vasil'eva LV, Sidel'nikova VI, Vasil'chenko TD. [Clinicogenetic parallels in infectious inflammatory diseases of the lungs]. Probl Tuberk. 1989;8:7-10. Russian [with English abstract].

47. Mozalevskii AF. [Polymorphic blood systems in children with bronchial asthma]. Tsitol Genet. 1985;19:220-225. Russian [with English abstract].

48. Lasmar LM, Camargos PA, Ordones AB, Gaspar GR, Campos EG, Ribeiro GA. Prevalence of allergic rhinitis and its impact on the use of emergency care services in a group of children and adolescents with moderate to severe persistent asthma. J Pediatr (Rio J). 2007;83(6):555-561.
Pediatric Health, Medicine and Therapeutics

\section{Publish your work in this journal}

Pediatric Health, Medicine and Therapeutics is an international, peerreviewed, open access journal publishing original research, reports, editorials, reviews and commentaries. All aspects of health maintenance, preventative measures and disease treatment interventions are addressed within the journal. Practitioners from all disciplines are invited to submit

\section{Dovepress}

their work as well as healthcare researchers and patient support groups. The manuscript management system is completely online and includes a very quick and fair peer-review system. Visit http://www.dovepress.com/ testimonials.php to read real quotes from published authors.

Submit your manuscript here: http://www.dovepress.com/pediatric-health-medicine-and-therapeutics-journal 